\title{
Characterisation of carcass composition and meat quality of male suckling buffalo calves kept on natural grassland
}

\author{
Gabriella Holló', Brigitta Barna1 and Karin Nuernberg² \\ 'University of Kaposvár, Kaposvár, Hungary, ²Leibniz Institute for Farm Animal Biology, Dummerstorf, Germany
}

\begin{abstract}
The aim of this observational study (field experiment) was to evaluate carcass composition and meat quality of male suckling buffalo calves. The animals were born between June and September 2011 and were kept on natural pasture in a cow/calf herd. From the end of November 2011, the suckling calves were fed only roughage as feed supplement in a feedlot until slaughter. For a generalised characterisation, the basic statistics of 18 male calves were calculated. The animals were slaughtered at an average live weight of $196.0 \mathrm{~kg}$. Growth, live weight development and most carcass traits varied substantially between individual calves. The 12th rib muscle composition measured by computer tomography indicated comparable meat contents as evaluated by manual dissection of the carcass. Meat quality parameters ( $\mathrm{pH}$ and colour) and the nutrient composition (protein, fat, ash) of longissimus muscle samples of calves were relatively similar. The intramuscular fat content of longissimus muscle was low, but shows a high variation between 0.3-1.1\%.
\end{abstract}

Keywords: buffalo calves, suckling, grazing, slaughter value

Abbreviations: CT: computer tomography

Archiv Tierzucht 56 (2013) 107, 1060-1065

doi: $10.7482 / 0003-9438-56-107$

Corresponding author:

Karin Nuernberg; email: knuernbg@fbn-dummerstorf.de

Institute Muscle Biology and Growth, Leibniz Institute for Farm Animal Biology, Wilhelm-Stahl-Allee 2, 18196

Dummerstorf, Germany

( 2013 by the authors; licensee Leibniz Institute for Farm Animal Biology (FBN), Dummerstorf, Germany.

This is an Open Access article distributed under the terms and conditions of the Creative Commons Attribution 3.0 License (http://creativecommons.org/licenses/by/3.0/).
Received: 9 December 2013 Accepted: 20 December 2013 Online: 12 March 2014 


\section{Introduction}

Buffaloes (Bubalus bubalis) are bred on all continents of the world. The river type can be found in the Mediterranean area, which includes parts of Europe, Northern Africa and countries of the Near East. A consistent number of buffaloes are recently reared in two European countries, Romania and Italy. In Italy, the number of buffaloes has increased due to the demand for particular buffalo milk products and since the buffalo is progressively being acknowledged as dairy cattle (Borghese 2004). In Africa, especially in Egypt, buffaloes are being considered as predominant dairy cattle breed (Mourad \& Khattab 2009), and male buffaloes are also being reared and fattened for meat production purposes (Shahin et al. 2010).

The buffalo was brought to the Carpathian Basin by the Avars (4th century). At the beginning of the 20th century the buffalo population in the Carpathian Basin was about 155000, of which the majority was kept in Transylvania (Tőzsér \& Bedő 2003). Today, only 1000 buffaloes are kept in Hungary, and they are recognized as genetic reserve and part of the country's cultural heritage. One of the most important buffalo reservations (100-150 animals) is located in the south-western part of the Lake of Kis-Balaton, belonging to the Balaton Uplands National Park (Barna \& Holló 2012). The vast marshland of the Kis-Balaton area is unfavourable for other ruminant species, but very suitable for buffalo breeding, since their digestive tract is highly adapted to the utilisation of low quality fibrous feeds (Terramoccia et al. 2000).

Consumer interests in buffalo meat products have substantially increased in recent years, but since national scientific data on meat animal performance and meat quality of Buffaloes are lacking, the present study aimed at evaluating the fattening performance and slaughter value of male suckling buffalo calves kept on natural grassland.

\section{Material and methods}

Male buffalo calves originated from the Hungarian National Buffalo Reservation, Kápolnapuszta, Balaton Uplands National Park. Animals $(n=18)$ were born in June $(n=6)$, in August $(n=6)$ and in September $(n=6) 2011$ and were slaughtered on two occasions (in February and in March 2012) at a live weight of $196.1 \pm 34.7 \mathrm{~kg}$. The animals were kept in a cow/calf herd on natural pasture from birth until the end of November. During the winter, the suckling calves were given a supplementary feeding (only grass hay; no concentrate). The calves followed their mothers and could suckle freely from birth to slaughter. The animals were slaughtered immediately after arrival at the abattoir according to the Hungarian standards. The carcasses were assessed for conformation (an 18 point scale: scale 1 (poorest) to 18 (best)) and fatness (a 15 point scale: scale 1 (leanest) to 15 (fattest)) according to EU beef carcass classification scheme. At slaughter: live weight, hot carcass weight, fat depot (kidney) proportion and EU classification data were recorded. After a 24-hours chilling, the right half of the carcasses was dissected; lean meat, fat, bone, tendon, composition (\%) were determined. Lean meat was separated according to 1st choice meat including sirloin, inside round, topside, eye of round, silverside, tenderloin, prime rib and shortloin; 2nd choice meat including shoulder, shoulder blade and top blade; 3rd choice meat including shin, shank, neck and chuck as well as other not identified ( 2 nd and 3rd choice) meat cuts. Samples from 
the 12th rib were removed from the right half of the carcass, for X-ray computer tomography (CT) analysis. Computer tomography analysis of rib samples was performed by using the Siemens Emotion 6 at the Institute of Diagnostic Imaging and Radiation Oncology of the University of Kaposvár (Hungary). Tissues were differentiated as previously described (Holló et al. 2007). Meat colour and $\mathrm{pH} 24$ were measured with a Minolta chromameter CR-410 and a Hanna HI 99163 portable pH-meter, resp. The chemical composition of longissimus muscle of 12th rib sample was analysed at the Analytical Laboratory of the University. Data were evaluated using SPSS 17.0 statistical software (SPSS Inc., Chicago, IL, USA). In Tables, means, standard deviations, minimum and maximum values are presented.

\section{Results and discussion}

Throughout the world, there are different management systems for buffalo calves reared for either milk or meat production. Due to the high price of buffalo milk in the Mediterranean area, buffalo calves are weaned (Infascelli et al. 2004). In contrast to this system, Hungarian farmers generally separate calves from their dams, but allow them to suckle limited amounts of milk to upkeep the dams' milk production (Barna \& Holló 2012). In the National Park, in which the current study was conducted, the main purpose of buffalo breeding is the conservation of species and the utilisation of the natural landscape. The term »buffalo calves« is generally used for animals weighting between $40 \mathrm{~kg}$ and $220 \mathrm{~kg}$. The buffalo growth rate curve showed a progressive increase in daily weight gain, reaching its peak at 303 days of age (180 kg) until 415 days (Infascelli et al. 2004). In our study animals were slaughtered at an average age of 223 days and an average live weight of $196 \mathrm{~kg}$ (Table 1). Comparing these findings with other dairy cattle breeds, Holstein (189 kg) and Simmental (196 kg) calves reached comparable live weights at six months of age, i.e. one month earlier (Ender et al. 2001). The average daily gain of our male calves was $903 \mathrm{~g} /$ day. According to Tripaldi et al. (2001), the daily gain of buffalo calves varied between 831-1 $160 \mathrm{~g} / \mathrm{d}$ depending on feeding method. Another study reported on lower, about 360-420 g/d daily live weight gain (Tauqir et al. 2011). Generally, it was described that buffaloes had significantly lower energy and protein requirements, lower daily weight gain and mean live weight than guidelines for calves of similar ages. Consequently, the low quality natural pasture can be utilised for buffalo breeding, moreover this achievement give adding value to the land and maximizing the sustainable use of the land.

Table 1

Slaughter data of male buffalo calves

\begin{tabular}{lrrrr}
\hline & Mean & SD & Min & Max \\
\hline Slaughter weight, kg & 196.06 & 34.72 & 135.00 & 270.00 \\
Slaughter age, d & 223.39 & 38.68 & 177.00 & 290.00 \\
Daily gain, g/d & 901.65 & 212.27 & 465.52 & 1377.55 \\
Hot carcass weight, kg & 100.01 & 19.79 & 54.60 & 138.40 \\
EUROP meat score, point & 4.83 & 0.71 & 2.00 & 5.00 \\
EUROP fat score, point & 4.61 & 0.85 & 3.00 & 6.00 \\
Carcass yield,\% & 50.86 & 4.05 & 40.44 & 58.97 \\
Kidney fat percentage, \% & 1.61 & 0.38 & 0.73 & 2.11 \\
\hline
\end{tabular}


The gain of progeny and maternal performance on pasture was influenced mainly by weather conditions. In April and May of experimental period the precipitation was critical for grass growth; however, cool and rainy weather in July may improve plant production, but was not favourable for calves which were born in early summer. In contrast, dry and hot weather in August and September had positive influence on performance of dams and calves born in August and September. As a consequence, the values of daily gain for buffalo male calves in our study showed a high individual variation (466-1 378 g/d).

There are no data about slaughter performance of suckling male buffalo calves raised on pasture. Failla et al. (2001) reported on higher dressing percentage (52\%) and conformation score (6.1) and lower fat score (5.6) for buffaloes fed only skimmed milk until slaughtering, compared to our values. In our study, the hot carcass weight of buffalo calves follows the tendency of slaughter weight and was similar to those values which were measured at six months of age slaughtered Holstein bull calves (Ender et al. 2001). In Holstein, the carcass yield of male calves was on average $52.5 \%$ and the kidney fat proportion $1.9 \%$ (Ender et al. 2001). The highest kidney fat percentage measured in a buffalo calf was $2 \%$; it seems that kidney fat proportion changed in line with daily gain values.

The percentage of meat in the right halves of the carcasses varied between $59 \%$ and $66 \%$ (Table 2.). The highest fat percentage exceeded $9 \%$, whilst the lowest was $2.6 \%$. In literature, higher meat and lower bone percentages was detected in weaned yearling buffalo calves (Mahmoudzadeh \& Fazaeli 2009). For bovines, Ferrara \& Infascielli (1994) found similar percentages of meat in the carcasses (about $62 \%$ ), due to the lower bone incidence ( $16.9 \%$ vs. $20.2 \%)$ but higher fat content (21.2\% vs. $18.1 \%)$ in buffaloes. In comparison to Holstein calves slaughtered at similar weights (Ender et al. 2001), our buffalo calves had lower fat and higher bone contents in the carcass. The muscle tissue content in 12th rib sample measured by CT showed a similar tendency as lean percentage of carcass. The tissue composition of 12th rib sample measured by CT showed more fat and tendon percentage and less bone content than tissue composition of dissected carcass. Comparing CT (at 12th rib) and EUROP classification results, higher correlation was detected between CT measured meat percentage of the carcass $(r=0.7)$ and the manual cutting as with the EUROP system measured meat percentage $(r=0.55)$. We observed any associations for fat, among fat content of carcass and EUROP fat score as well as CT fat in 12th rib.

Table 2

Dressing data (\%) of buffalo male calves by two different methods

\begin{tabular}{lrrrr}
\hline & Mean & SD & Min & Max \\
\hline Carcass (manual dissection) & & & & \\
$\quad$ Meat & 62.33 & 1.89 & 59.31 & 65.91 \\
Fat & 5.95 & 1.61 & 2.59 & 9.18 \\
Bone & 27.43 & 2.48 & 24.81 & 33.57 \\
$\quad$ Tendon & 4.29 & 0.37 & 3.49 & 4.91 \\
22th rib (CT) & & & & \\
$\quad$ Muscle tissue & 63.15 & 6.98 & 49.56 & 72.31 \\
Fat tissue & 12.53 & 2.15 & 8.78 & 15.29 \\
Bone tissue & 15.90 & 2.79 & 12.50 & 22.71 \\
Connective tissue & 8.42 & 2.95 & 5.13 & 14.30 \\
\hline
\end{tabular}


The amounts of twelve commercially relevant beef cuts in carcasses of buffalo calves are presented in Table 3. The total proportion of 1st choice meat was on average $43 \%$. This value is lower than that of Holstein bulls slaughtered at 203 days of age (Szabó et al. 2002). The average proportion of whole round (sirloin, inside round, topside, eye of round and silverside) was $33 \%$. Buffaloes had a higher forequarter percentage and lower rump percentage than bovines (Vaz et al. 2012). Concerning male calves, the opposite tendency was obtained; buffalo calves had a higher round and shin+shank percentage and a lower tenderloin, shoulder, neck prime rib and short loin proportion compared to values of same meat cuts of Holstein and Simmental calves (Ender et al. 2001).

Table 3

Commercial meat cuts (\%) proportion of buffalo male calves

\begin{tabular}{lrrrr}
\hline & Mean & SD & Min & Max \\
\hline Sirloin,\% & 5.79 & 0.19 & 5.38 & 6.06 \\
Inside round, \% & 7.19 & 0.43 & 6.55 & 8.04 \\
Topside, \% & 9.32 & 0.30 & 8.72 & 9.82 \\
Eye of round+Silverside, \% & 10.94 & 0.30 & 10.44 & 11.54 \\
Tenderloin,\% & 2.14 & 0.09 & 1.94 & 2.31 \\
Prime rib,\% & 3.92 & 0.39 & 3.10 & 4.36 \\
Shortloin,\% & 3.34 & 0.30 & 2.84 & 4.11 \\
Shoulder,\% & 6.67 & 0.36 & 5.90 & 7.41 \\
Top blade+Shoulder blade, \% & 4.58 & 0.32 & 4.13 & 5.25 \\
Shin+shank, \% & 11.30 & 0.51 & 10.04 & 12.11 \\
Neck,\% & 6.22 & 0.75 & 5.08 & 7.88 \\
Chuck, \% & 4.03 & 0.42 & 3.18 & 4.76 \\
Proportion of other & 24.57 & 1.23 & 20.87 & 26.24 \\
(second and third class) meat, \% & & & & \\
\hline
\end{tabular}

The average pH-value measured in the longissimus muscle was 5.77 (Table 4). It is well known that the pigment content of muscle was affected by both age and diet of animals. Intramuscular fat content and composition of cattle veal is affected by many factors. The intramuscular fat level of longissimus muscle varied between 0.33-1.09, and showed a similar tendency as fat content in carcass as well as fat percentage in 12th rib sample. In Simmental and Holstein bull calves slaughtered at similar weight Ender et al. (2001) detected for intramuscular fat percentage $0.23 \%$ and $0.64 \%$. In our study, dry matter and protein content were higher than those values measured at six months old buffalo calves (Infascelli et al. 2004). Moreover, our calves deposited less fat in muscle due to the extensive rearing conditions compared to calves of abovementioned trial.

Table 4

Chemical composition (\%) of longissimus muscle and meat quality of male buffalo calves

\begin{tabular}{lrrrr}
\hline & Mean & SD & Min & Max \\
\hline Dry matter & 23.63 & 1.00 & 20.80 & 24.70 \\
Protein & 20.99 & 0.77 & 18.90 & 22.50 \\
Fat & 0.63 & 0.21 & 0.33 & 1.09 \\
Ash & 1.06 & 0.05 & 0.95 & 1.11 \\
pH24 & 5.77 & 0.10 & 5.52 & 5.92 \\
$\mathrm{~L}$ & 40.91 & 1.98 & 36.59 & 47.09 \\
\hline
\end{tabular}


In conclusion, one opportunity of low quality natural pasture utilisation is buffalo breeding and keeping. This achievement adds value to the land and maximizes the sustainable use of the land. The gain performance of suckling male buffalo calves is low under extensive rearing conditions and it is also affected by weather conditions. The carcass value is similar to male weaned Holstein calves, although buffalo carcasses contain lower fat and higher bone percentages due to the extensive keeping.

\section{References}

Barna B, Holló G (2012) [The breeding of buffalo in Hungary]. Anim Welfare Ethol Hous Syst 8, 19-35 [in Hungarian]

Borghese A (2009) Present Situation and Future Prospective of Buffalo Production in Europe and Near East Pakistan. J Zool Suppl Ser 9, 491-502

Ender B, Nuernberg G, Ender K, Szűcs E (2001) [Comparison of red spotted and Holstein-Friesian young fattening bulls' quality during growth]. Hung J Anim Prod 50, $317-332$ [in Hungarian]

Failla S, Gigli S, Bisegna V, Di Giacomo A (2001) [Production of calf bufallo white meat fed with two different types of milk. Note I: productive performances]. In: Proc 1st Natl Congr Buffalo Breed, Eboli, Italy, 277-280 [in Italian]

Ferrara B, Infascelli F (1994) Invited lecture: Buffalo meat production: consumption, quality, carcass, subproducts. In: Proc. IV World Buffalo Congress, Sao Paulo, Brasil, 1, 122-136

Holló G, Szűcs E, Tőzsér J, Holló I, Repa I (2007) Application of X-ray Computer Tomography (CT) in Cattle Production. Asian-Aust J Anim Sci 20, 1901-1908

Infascelli F, Gigli S, Campanile G (2004) Buffalo Meat Production: Performance infra vitam and Quality of Meat. Vet Res Comm 28 (Suppl.), 143-148

Mahmoudzadeh H, Fazaeli H (2009) Growth response of yearling buffalo male calves to different dietary energy levels. Turk J Vet Anim Sci 33, 447-454

Moreno T, Varela A, Oliete B, Carballo JA, Sánchez L, Montserrat L (2006) Nutritional characterstics of veal from weaned and unweaned calves: Discriminatory ability of the fat profile. Meat Sci 73, 209-217

Mourad KAM, Khattab AS (2009) A comparison between different selection indices for some productive traits on Egyptian buffaloes. Arch Tierz 52, 476-484

Shahin KA, Abdallah OY, Fooda TA, Mourad KA (2010) Selection indexes for genetic improvement of yearling weight in Egyptian buffaloes. Arch Tierz 53, 436-446

Sharma KC, Sachdeva VK, Singh S (2000) A comparative gross and lipid composition of Murrah breed of buffalo and cross-bred cow's milk during different lactation stages. Arch Tierz 43, 123-130

Spanghero M, Gracco L, Valusso R, Piasentier E (2004) In vivo performance, slaughtering traits and meat quality of bovine (Italian Simmental) and buffalo (Italian Mediterranean) bulls. Livest Prod Sci 91, 129-141

Szabó F, Polgár JP, Farkasné Zele E, Lengyel Z, Holló I (2002) [Some new data on the slaughter results, carcass traits and chemical composition of muscles of Holstein-Friesian bulls at different ages]. Hung J Anim Prod 51, 577-585 [in Hungarian]

Tauqir NA, Shahzad MA, Nisa M, Sarwar M, Fayyaz M, Tipu MA (2011) Response of growing buffalo calves to various energy and protein concentrations. Livest Sci 137, 66-72

Terramoccia S, Bartocci S, Amici A, Martillotti F (2000) Protein and protein-free dry matter rumen degradability in buffalo cattle and sheep fed diets with different forage to concentrate ratios. Livest Prod Sci 65, 185-195

Tőzsér J, Bedő S (eds.) (2003) [Encyclopaedia of Historical Animal Breeds]. Mezőgazda Publisher, Budapest, Hungary [in Hungarian]

TripaldiC, FaillaS, Verna M, Roncoroni C (2001) [Breast-feeding of buffalo calves: composition and concentration of the reconstituted milk]. In: Proc 1st Natl Congr Buffalo Breed, Eboli, Italy, 399-403 [in Italian]

Vaz FN, Vaz RZ, Pascoal LL, Restle J, Leal WS, de Ávila MM (2012) Economical Analysis and Commercial Cuts Yields of Buffaloes and Bovines of Both Sexes. J Anim Prod Adv 2, 436-444 